\title{
Population Persistence and Offspring Fitness in the Rare Bellflower Campanula cervicaria in Relation to Population Size and Habitat Quality
}

\author{
ANNA-KAIJA EISTO, ${ }^{*} \dagger$ MARKKU KUITUNEN, ${ }^{*}$ ANTTI LAMMI, ${ }^{*} \ddagger$ VELI SAARI, $*$ \\ JUKKA SUHONEN, ${ }^{*}$ SUSANNA SYRJÄSUO,${ }^{*}$ AND PÄIVI M. TIKKA*』 \\ *Department of Biological and Environmental Science, University of Jyväskylä, P.O Box 35 (YAC), FIN-40351 \\ Jyväskylä, Finland \\ †Forest and Park Service, Urheilukatu 3 A, FIN-81700 Lieksa, Finland \\ ‡South West Finland Regional Environment Centre, P. O. Box 47, FIN-20801 Turku, Finland
}

\begin{abstract}
Data from several animal species and a few plant species indicate that small populations face an elevated risk of extinction. Plants are still underrepresented in these studies concerning the relation between population size and persistence. We studied the effect of population size on persistence among natural populations of the rare bellflower Campanula cervicaria in Finland. We monitored 52 bellflower populations for 8 years and found that the mean population size decreased from 24 to 14 during this period. Small populations with $\leq 5$ individuals were more prone to losing all fertile plants than were larger ones. Reduction in population size was nevertheless unrelated to the degree of population isolation, measured as the distance to the nearest known population. To test the bypothesis that offspring fitness is lower in small populations, we germinated bellflower seeds from different-sized populations in a laboratory and found that seed germination ability was independent of population size. The seedlings raised from seeds of small populations grew faster than those taken from larger populations. Population size was negatively related to the amount of shade in the babitats. In conclusion, decreasing population sizes of $\mathrm{C}$. cervicaria seemed not to be caused by lowered germination ability or growth rate in small populations; rather, population size reductions appeared to be due to closing of vegetation in the babitats.
\end{abstract}

Persistencia Poblacional y Adaptabilidad de Crías en la Especie Rara Campanula cervicaria con Relación al Tamaño Poblacional y la Calidad del Hábitat

Resumen: Los datos de varias especies de animales y de unas pocas especies de plantas indican que las poblaciones pequeñas enfrentan un riesgo elevado de extinción. Las plantas están aún menos representadas en estos estudios concernientes a la relación entre el tamaño poblacional y la persistencia. Nosotros estudiamos el efecto del tamaño poblacional sobre la persistencia de poblaciones naturales de la rara Campanula cervicaria en Finlandia. Monitoreamos 52 poblaciones de C. cervicaria por 8 años y encontramos que el tamaño promedio poblacional disminuyó de 24 a 14 durante este periodo. Las poblaciones pequeñas con $\leq 5$ individuos fueron más propensas a perder todas las plantas fértiles que las poblaciones grandes. Sin embargo, la reducción en el tamaño poblacional no estuvo relacionada con el grado de aislamiento poblacional, medido como la distancia a la población más cercana. Para evaluar la bipótesis de que la adaptabilidad de la progenie es menor en poblaciones pequeñas, germinamos semillas de C. cervicaria de diferentes tamaños poblacionales en un laboratorio y encontramos que la germinación de semillas fue independiente del tamaño poblacional. Las plántulas provenientes de poblaciones pequeñas crecieron más rápido que aquéllas tomadas de poblaciones más grandes. El tamaño poblacional estuvo negativamente relacionado con la cantidad de sombra en los bábitats. En conclusión, la disminución del tamaño poblacional de C. cervicaria aparente-

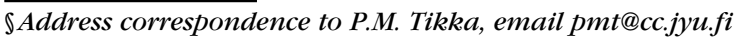

${ }^{*}$ The names of the autbors are presented in alphabetical order.

Paper submitted June 7, 1999; revised manuscript accepted December 28, 1999. 
mente no es causada por una disminución en la babilidad de germinación o en la tasa de crecimiento, más bien, parece ser que las reducciones en el tamaño poblacional son debidas a lo cerrado de la vegetación en los hábitats.

\section{Introduction}

Destruction, fragmentation, and degradation of the environment often create small and isolated populations (Andrén 1994; Meffe \& Carroll 1997), and small populations are more prone to extinction than larger ones (Shaffer 1981; Schoener \& Spiller 1992; Ouborg 1993; Lynch et al. 1995). An elevated risk of local extinction is connected to the fact that demographic, genetic, and environmental stochasticity affect small populations more severely than larger populations (Lande 1988; Ellstrand 1992; Primack 1993; Gomulkiewicz \& Holt 1995; Groom 1998). The role and significance of these stochastic events, however, vary greatly between taxa and populations. An association between small population size and an increased risk of extinction is more often reported for animals (Diamond 1984; Schoener \& Spiller 1987, 1992; Pimm et al. 1988; Hanski et al. 1995) than for plants (Ouborg 1993; Newman \& Pilson 1997). Small and fragmented plant populations, however, are presumed less viable than larger ones because of related processes such as the loss of genetic polymorphism (Karron 1987; Raijmann et al. 1994), inbreeding depression (Ellstrand \& Elam 1993), and reduced pollination success (Jennersten \& Nilsson 1993; Ågren 1996; Kearns \& Inouye 1997). Genetic, environmental, and management factors can also have combined effects on population viability that are not detectable if analyzed independently (Menges \& Dolan 1998).

In northern Europe, one group of plants exhibiting a dramatic decline in population numbers and size are species typical of seminatural grasslands. Their habitats have become scarce and isolated as a consequence of reforestation, transformation to arable fields, and cessation of hay making, grazing, and clearing by burning. In Finland as much as $25 \%$ of the plant species under threat have their optimal occurrence in seminatural grasslands such as meadows, pastures, and glades (Rassi et al. 1992). These species suffer from shading and from competition by tall plants that invade habitats following changes in land use (Armesto \& Pickett 1985; Zobel 1992). Many grassland plants, however, have been able to move to alternative, open habitats, such as road and railway verges (Tikka et al. 2000). These habitats may compensate for the isolation of remaining seminatural grasslands and enable their plant populations to form metapopulations in which species persist by moving from destroyed habitat patches to suitable patches nearby (Eriksson 1996).
We conducted an extensive, multiyear survey of a rare, monocarpic grassland herb, the bellflower (Campanula cervicaria $\mathrm{L}$ ), in Finland. We sought to identify the reasons for its decline and to outline measures for its preservation. As a relatively short-lived, monocarpic species, C. cervicaria has a higher risk of population extinction than perennial or clonal plants (Fischer \& Stöcklin 1997). For grassland plants, habitat quality (i.e., openness) is important. We therefore tested the effects of shading by field-layer vegetation, shrubs, and trees on the performance of $C$. cervicaria populations. We studied the effects of population size and isolation on the short- and longer-term persistence of bellflower populations and tested the hypothesis that offspring fitness of individuals in small populations is lower than that of individuals in larger ones. The results of earlier studies on plant populations either support this prediction (Menges 1991; Heschel \& Paige 1995, Fischer \& Matthies 1998) or contradict it (Widén 1993; Hauser \& Loeschcke 1994; Ouborg \& van Treuren 1995; Kunin 1997; Lammi et al. 1999). Moreover, it is a matter of debate at what stage of the reproductive cycle possible effects on fitness are expressed (Widén 1993; Oostermeijer et al. 1994a; Waser \& Price 1994).

The main questions we addressed were as follows: (1) Is the persistence of populations related to population size or degree of isolation? (2) Is there any association between current population size and seed germination ability or the growth of seedlings? (3) Is there any association between former variations in population size and seed germination ability or the growth of seedlings? (4) Are population size, seed germination ability, or growth of seedlings related to the coverage of surrounding vegetation?

\section{Methods}

\section{The Study Species}

In the first summer after germination, $C$. cervicaria develops a rosette and in the second summer, or later, a flowering shoot. Its light blue flowers form groups in the axils and the end of its $30-$ to $150-\mathrm{cm}$-high stem. An average individual has a couple of dozen protandrous flowers that are usually pollinated by bumble bees (Bombus spp) or syrphid flies (Syrphidae spp), and one flower produces on average 200-300 seeds (Nurmi 1980, 1998; Eisto 1990). Spontaneous self-pollination occurs when the access of pollinators to flowers has been blocked, 
but it results in a lower level of seed production than that achieved by insect pollination (Eisto 1990). The origin of the species is in western Siberia. In Europe it occurs from the Mediterranean countries to Fennoscandia but is rare in southern Europe and already extinct in Denmark and Belgium (Hultén \& Fries 1986). In Finland the species is an archaeophyte (in that it arrived with prehistoric immigrating people). Germination of its seeds is dependent on light (Often 1999), and it used to grow primarily in glades resulting from clearing by burning. These glades have returned to forest, so $C$. cervicaria now occurs in alternative open habitats such as meadows, abandoned fields, and grassland strips by road verges and under power lines (Ryttäri \& Kettunen 1997; Nurmi 1998). The species has regressed and has been classified as "near threatened" in Finland (Rassi et al. 1992; Kanerva et al. 1998).

\section{Location of Populations and Estimation of Population Sizes}

The $C$. cervicaria populations we studied were situated in the region of central Finland (lat $62^{\circ} \mathrm{N}$, long $24^{\circ} \mathrm{E}$ ) where information on former distribution of the species was available. In the first phase of our study, we compiled records of the occurrence (within the last 50 years) of $C$. cervicaria from regional and local authorities, nature conservation associations, and local botanists. We also used herbarium records and published reports (for details, see Välivaara et al. [1991]). We surveyed all recorded $C$. cervicaria habitats in the field during the summers of 1987-1989 and, using field maps (scale 1:20 000), searched for sites that might be suitable for $C$. cervicaria. We located 52 flowering bellflower populations. We considered that plants belonged to separate populations if the distance between them was $>100 \mathrm{~m}$. Most of the bellflower populations occurred on disturbed habitats such as road and railway verges $(n=40)$, hereafter called roadside populations. The remainder of the populations ( $n=12$ ) were found in abandoned fields, powerline corridors, and dry meadows, hereafter called meadow populations. Each of these populations was reexamined in 1995.

We determined population size as the number of flowering, fertile individuals. The number of fertile plants does not indicate the exact population size because populations always also include sterile rosettes. The abundance of fertile individuals, however, serves as a good indicator of the population's viability. Fertile plants were counted exactly. The number of fertile plants at the first population check from 1987 to 1989 is referred to as the initial population size. We found 43 of the 52 populations already in the first study year of 1987, and these 43 populations were surveyed annually to determine shortterm population changes during 1987-1989. Longerterm change in population size for all the 52 populations was measured as the difference between the initial pop- ulation size and the population size in 1995. We measured the degree of isolation of each population as the distance to the nearest known population. The size of the nearest population was also determined.

\section{Variations in Population Size, Germination Ability, and Growth Rate}

For the second part of this study, we counted fertile plants in 26 easily accessible $C$. cervicaria populations from 1996 to 1998 . Of these populations, 18 had already been included in 1987-1989, and the rest were found later in connection with field studies. We calculated the current population size for each of the 26 populations as the mean of population sizes between 1995 and 1998. Because large variations in population size decrease effective population size, presumably affecting reproductive success (Primack 1993; Frankham 1995), we also studied the long-term variation of populations. To do this, we calculated the average population size in the 1980s for each population (the mean size in 19871989), average population size during the entire period (1987-1998), and the relative range, indicated as a percentage of the maximum population size during the entire period ([maximum - minimum] $\times 100 /$ maximum).

We collected seeds from the 26 populations in September 1996. In 2 populations, however, seeds were unripe and had to be excluded, so we had usable seeds from 24 populations. In 1997 only 19 of the populations had fertile individuals, and their seeds were collected in October. After collection, the seeds were stored in a cold room at $5^{\circ} \mathrm{C}$ for 4 months. To determine the germination ability of seeds after cold stratification, we placed 50 seeds collected from one naturally pollinated plant per population on moistened paper in petri dishes. To achieve comparability between populations, we chose to use seeds from one completely randomly selected plant per population in all germinations and raisings of seedlings because the smallest populations had only a single fertile individual. In 1996 the seeds were germinated at $20^{\circ} \mathrm{C}$ under an $80-\mathrm{W} / \mathrm{m}^{2}$ light regime of 12 hours light/12 hours dark for 4 weeks. To stimulate germination, in 1997 we changed the conditions as follows: $22^{\circ} \mathrm{C}$ with $380-\mathrm{W} / \mathrm{m}^{2}$ light (12 hours light/12 hours dark). After 4 weeks, we calculated germination percentages using the emergence of cotyledons as a sign of germination. To achieve a bit wider figure of germination ability, we also calculated the germination percentage by population as the mean of the values obtained in 1996 and 1997. In 1997 we weighed 50 randomly chosen seeds from each population to study the relationships between seed weight and population size, germination percentage, and seedling weight.

To compare the growth of seedlings between populations, 10 seedlings from each population were grown at $22^{\circ} \mathrm{C}$ for 8 weeks in both 1996 and 1997. During this 
time, they received $380-\mathrm{W} / \mathrm{m}^{2}$ light for 12 hours per day. Five to 10 seeds were sown per pot (diameter $2 \mathrm{~cm}$ ) in two $38 \times 60 \times 7.5 \mathrm{~cm}$ boxes. The boxes were covered with plastic to hold the moisture in, and the seedlings were watered daily. If more than one seedling per pot emerged, extra seedlings were removed randomly after 2 weeks. The soil was a mixture of fertilized compost (Vapo, Inc.) and vermiculite (Vermipu, Inc.) in a 2:1 ratio. After 8 weeks the seedlings were harvested to determine their aboveground biomass. Before weighing, the seedlings were dried in an oven at $70^{\circ} \mathrm{C}$ for 48 hours. In addition to determining the biomass per population separately in both years, we also took the average seedling biomass for each population as the mean of the values obtained in 1996 and 1997.

\section{Vegetation Analyses}

To evaluate the influence of co-occurring vegetation on the performance of $C$. cervicaria, we chose 23 of the 26 populations for vegetation analyses in 1998. (We excluded the 3 populations that seemed to be temporary, being occupied only 1 or 2 years.) We drew a straight line at random across the populations and marked five quadrats $(1 \times 1 \mathrm{~m})$ at equal intervals along the line. We then made a visual estimate of the percent coverage of all the vascular plant species growing in each square and the canopy coverage resulting from the trees and shrubs that shaded the quadrats. We summed the coverage of each vascular plant species in each quadrat to determine the total coverage of field-layer vegetation. We used the mean of the total coverages obtained from the five quadrats as a measure of field-layer coverage and of tree and shrub canopy coverage in each population.

\section{Data Analysis}

The numbers of populations used for different measurements and analyses are summarized in Table 1 . The values of initial population size (in 1987-1989) and population size in 1995, the size of the nearest neighboring population, and the distance between the neighboring populations were $\log _{10}$-transformed for a logistic regression analysis. We used this analysis to test whether the initial population size, the degree of isolation, the size of the nearest population, and the habitat type (roadside or meadow) affected the persistence of populations (binary dependent variable: no fertile plants, 1 ; fertile plants present, 0). The change in population size from the $1980 \mathrm{~s}$ to 1995 was tested with a paired $t$ test. Difference in germination ability between 1996 and 1997 was tested with a Wilcoxon test and difference in seedling growth with a paired $t$ test. Spearman rank correlation was used to test the associations between germination percentage, seedling biomass, coverage of surrounding vegetation, and the variables related to population size and variation. All the analyses were performed with SPSS for Windows (Version 7.5).

\section{Results}

\section{Population Persistence and Variation of Population Size}

The initial sizes of the 52 bellflower populations ranged from 1 to 240 fertile plants. In almost half the populations the initial size was $\leq 5$ fertile plants. Annual monitoring of 43 of the 52 populations for short-term persistence revealed that 16 populations had lost all their fertile plants by 1989. The proportion of populations losing every fertile individual was greatest in the smallest populations of 5 or fewer plants (Fig. 1a). The number of fertile plants in 1995 was positively correlated with initial population size $\left(r_{s}=0.58, n=52, p<\right.$ $0.001)$. By 1995, however, the average population size had decreased. The mean number of fertile individuals had dropped from $23.6(\mathrm{SD}=40.6)$ to $13.6(\mathrm{SD}=41.1)$ $(t=3.81, \mathrm{df}=51, p=0.001)$. Of the 52 populations, 44 had fewer fertile plants than initially (Fig. 2). Moreover, nearly half the populations ( 24 out of 52 ) had lost all fertile individuals within these 8 years, and the proportion of losses was once again highest in the smallest populations (Fig. 1b). On the other hand, 6 of the populations that had lost all fertile individuals during the period 1987-1989 had 1-3 fertile plants in 1995.

The minimum distance between two known populations varied from $100 \mathrm{~m}$ to $22 \mathrm{~km}$. According to the logistic regression model, the probability of losing all fertile plants was influenced only by the initial population size (Table 2). The effects of distance to the nearest population, the number of fertile individuals in the nearest population, and the habitat type were insignificant. According to the logistic regression model based solely on initial population size $\left(\chi^{2}=\right.$ 5.69, $\mathrm{df}=1, p=0.017$ ), the risk of losing all fertile individuals within 8 years was over $50 \%$ for bellflower populations with $\leq 5$ fertile plants. On the other hand, the probability of population size falling to zero in populations with 100 or more fertile individuals was predicted as $<20 \%$ (Fig. 3; based on data in Fig. 2).

Table 1. The numbers of $C$. cervicaria populations used for different measurements and analyses in this study.

\begin{tabular}{lc} 
Measurement or analysis & Number of populations \\
\hline Initial population size & 52 \\
Short-term population change & 43 \\
Long-term population change & 52 \\
Mean population size in 1980s & 52 \\
Current population size & 26 \\
Germinations in 1996 & 24 \\
Germinations in 1997 & 19 \\
Vegetation analyses & 23 \\
\hline
\end{tabular}


Table 2. Logistic regression models for probability of $C$. cervicaria populations in central Finland losing all fertile individuals in the short and long term.

\begin{tabular}{|c|c|c|c|}
\hline \multirow{2}{*}{$\begin{array}{l}\text { Regression model } \\
\text { variables }\end{array}$} & \multicolumn{3}{|c|}{$\begin{array}{c}\text { Significance of } \\
\text { independent variables }\end{array}$} \\
\hline & coefficient & $\chi^{2}$ & $\mathrm{p}$ \\
\hline \multicolumn{4}{|l|}{$\begin{array}{l}\text { Short term losses } \\
\quad\left(\text { from 1987-1989) }{ }^{a}\right.\end{array}$} \\
\hline constant & 3.64 & 6.91 & 0.009 \\
\hline $\begin{array}{l}\text { initial population size } e^{b} \\
\text { distance to the nearest }\end{array}$ & -5.19 & 10.90 & 0.001 \\
\hline population $^{b}$ & -0.31 & 0.21 & 0.65 \\
\hline population $^{b}$ & -0.81 & 0.73 & 0.39 \\
\hline $\begin{array}{l}\text { habitat type (roadside } \\
\text { or meadow) }\end{array}$ & 0.89 & 0.27 & 0.60 \\
\hline \multicolumn{4}{|l|}{$\begin{array}{l}\text { Long-term losses (from } \\
1987-1989 \text { to } 1995)^{c}\end{array}$} \\
\hline constant & 0.60 & 0.86 & 0.35 \\
\hline initial population size $^{b}$ & -1.15 & 4.74 & 0.03 \\
\hline $\begin{array}{l}\text { distance to the nearest } \\
\text { population }^{b}\end{array}$ & -0.67 & 2.30 & 0.13 \\
\hline $\begin{array}{l}\text { size of the nearest } \\
\text { population }^{b}\end{array}$ & 0.54 & 1.06 & 0.30 \\
\hline $\begin{array}{l}\text { habitat type (roadside } \\
\text { or meadow) }\end{array}$ & -0.65 & 0.57 & 0.45 \\
\hline
\end{tabular}

${ }^{a}$ Eighty-eight percent of cases correctly predicted.

${ }^{b} \log _{10}$-transformed.

${ }^{c}$ Seventy-three percent of cases correctly predicted.

The mean numbers of fertile individuals in the set of populations studied between 1995 and $1998(n=26)$ ranged from 0.5 to 133.8 , with an average of 25.5 (SD = 31.9). Interestingly, the mean size for these populations from the whole study period (1987-1998) and the relative range of population size were negatively correlated $\left(r_{s}=-0.50, n=26, p=0.01\right)$; variation in population size, indicating demographic stochasticity, was greatest in the smallest populations.

\section{Seed Germination, Growth of Seedlings, and Habitat Quality}

The mean seed germination percentage was $14.0 \%$ (SD $=$ $27.9)$ in 1996 and $64.3 \%(S D=38.7)$ in 1997; the difference between the years was significant $(t=-3.23, n=$ $17, p=0.001)$. Germination ability in both years was uncorrelated with population size of the year $(p>0.05)$. Similarly, mean germination percentage over the 2 years was unrelated to the current population size, taken as the mean in 1995-1998 $\left(r_{s}=-0.23, n=17, p=0.38\right)$. The average seedling biomasses did not differ in the 2 years $(t=-1.27$, $\mathrm{df}=14, p=0.226$ ), and seedling biomass was uncorrelated with population size in both years $(p>0.05)$. The mean seedling biomass over 1996-1997, however, was negatively associated with the current population size $\left(r_{s}=\right.$ $-0.56, n=15, p=0.028$ ). The mean germination percentage and mean seedling biomass were not correlated with each other $\left(r_{s}=0.32, n=15, p=0.24\right)$. Seed bio-
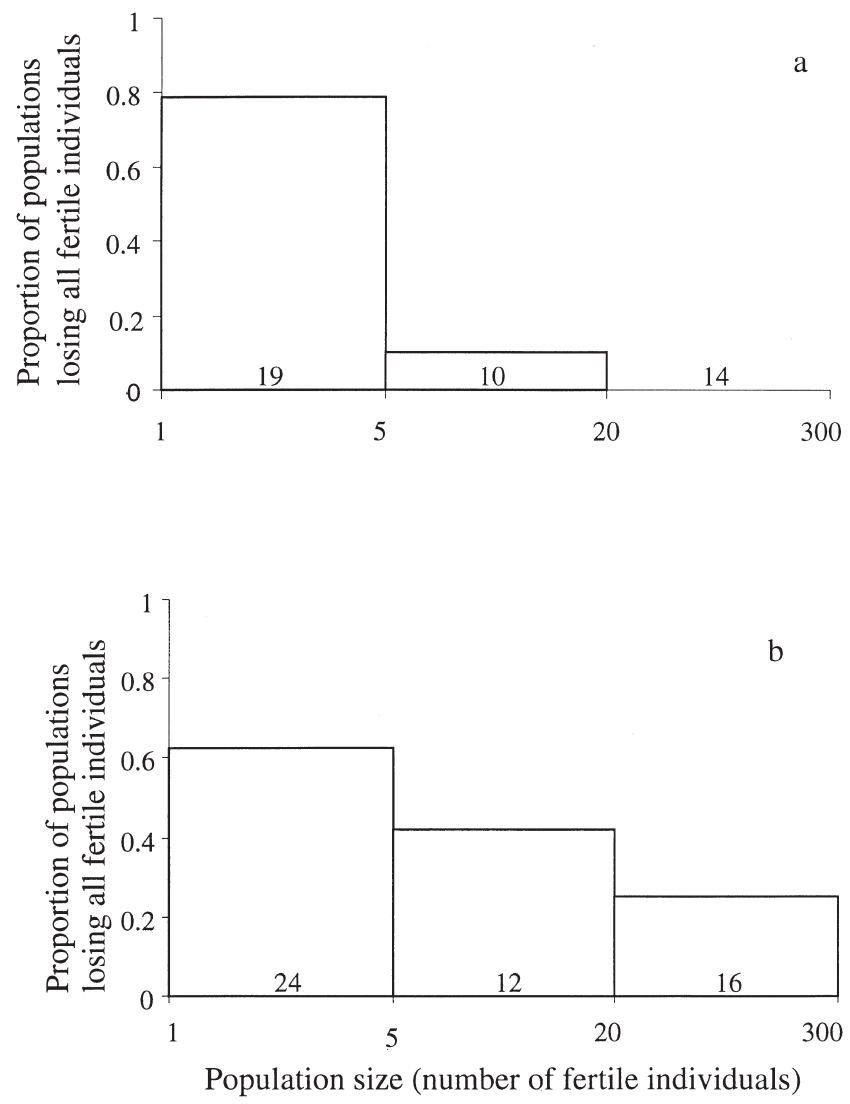

Figure 1. Relationship between initial population size of $\mathrm{C}$. cervicaria and the proportion of populations that lost all fertile individuals: (a) short-term losses during the years 1987-1989 and (b) long-term losses from the years 1987-1989 to 1995. Numerals inside bars indicate the number of populations in different size classes.

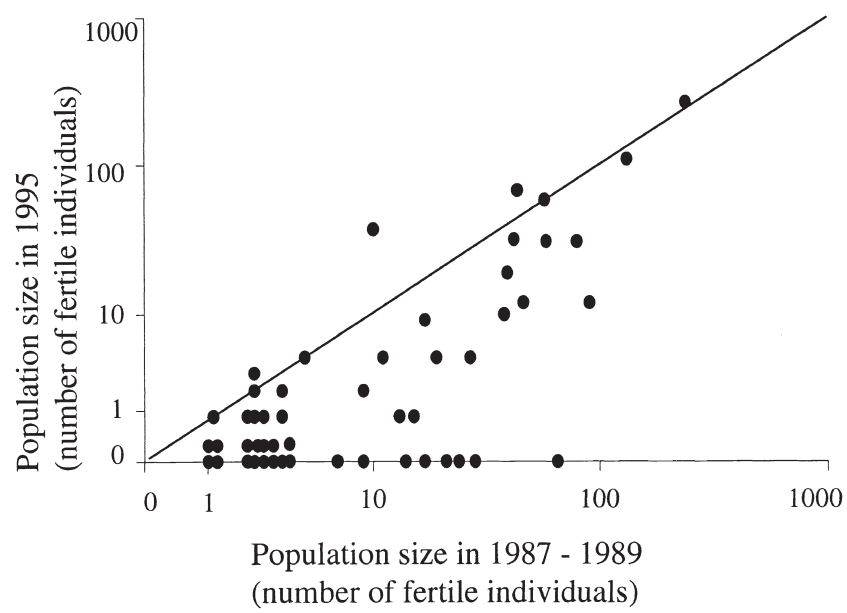

Figure 2. Population sizes of C. cervicaria in 1995 in relation to initial population sizes in 1987-1989. The population sizes are presented in a logarithmic scale. The reference line indicates a situation in which population size remains constant between the two periods. 


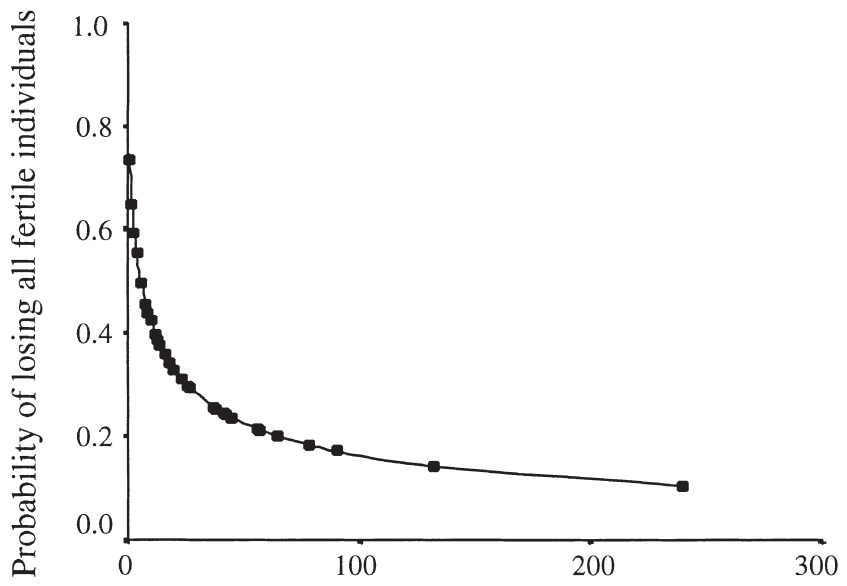

Population size (number of fertile individuals)

Figure 3. The predicted probability of losing all fertile C. cervicaria individuals, calculated by logistic regression analysis based on changes in population sizes between the years 1987-1989 and 1995. Points indicate observed population size and its predicted probability of falling to zero.

mass in 1997 was related only to seedling biomass $\left(r_{s}=\right.$ $0.581, n=19, p=0.009$ ), not to population size or seed germination percentage for that year.

When testing for the effect of variations in population size on seed germination, we found that the average germination percentage was unrelated to the average population size in the 1980s $\left(r_{s}=-0.04, n=12, p=0.91\right)$ or to the relative range of population size $\left(r_{s}=-0.18, n=\right.$ $17, p=0.49$ ). The average seedling biomass was also unaffected by these variables $(p>0.05)$.

The correlations between average germination percentage and total coverage of field-layer vegetation $\left(r_{\mathrm{s}}=\right.$ $0.19, n=17, p=0.47$ ), as well as the coverage of tree and shrub canopies $\left(r_{s}=-0.04, n=17, p=0.88\right.$ ), were not statistically significant. Even though current population size was independent of coverage by fieldlayer vegetation $\left(r_{s}=-0.21, n=23, p=0.33\right)$, it was negatively related to canopy coverage by trees and shrubs $\left(r_{s}=-0.47, n=23, p=0.024 ;\right.$ Fig. 4$)$. The longterm change in population size was not correlated with either field layer or canopy coverage $(p>0.05)$.

\section{Discussion}

Our results indicate that the studied C. cervicaria populations are in a state of general decline and that the risk of losing all fertile individuals increases with decreasing population size. We detected no change, however, in the levels of risk as a function of distance to the nearest population (i.e., geographic isolation) or the size of the
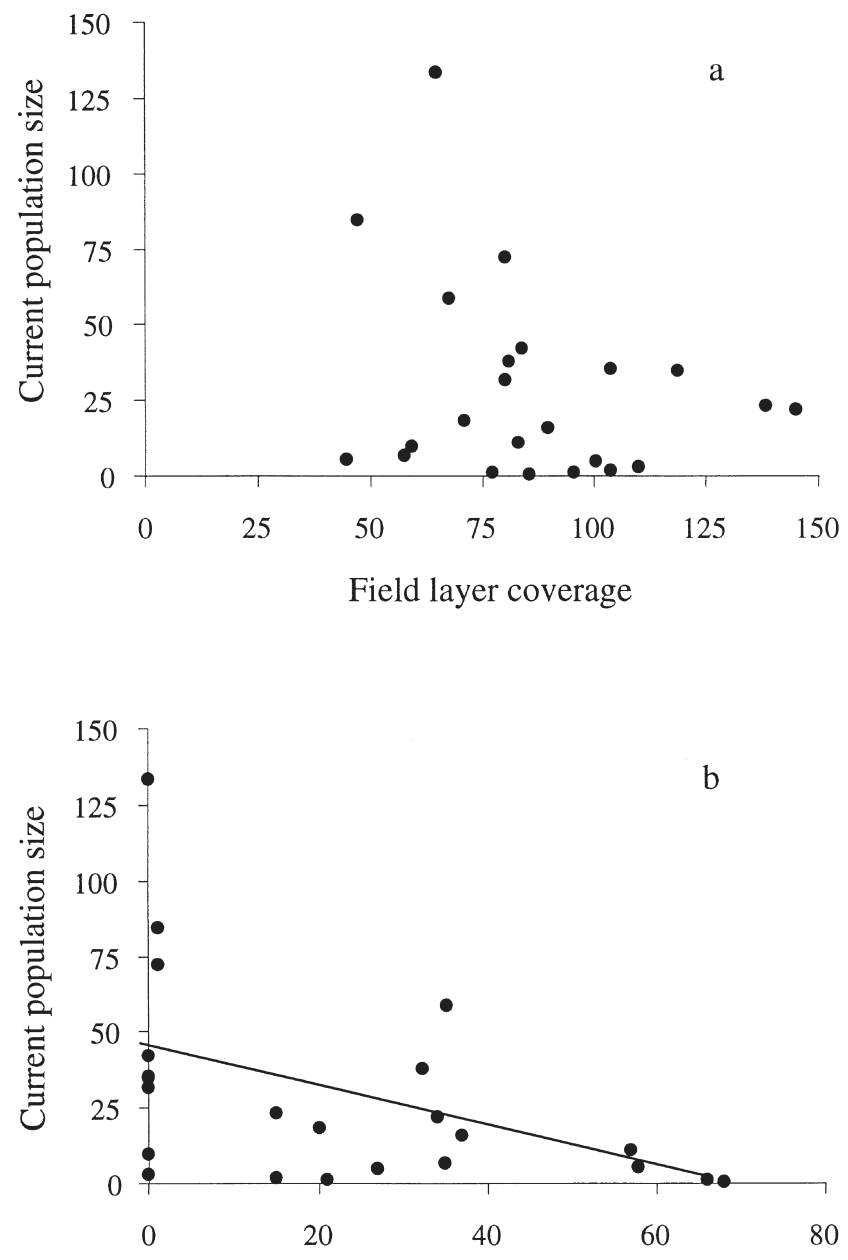

Tree and shrub canopy coverage

Figure 4. Current population size of $\mathrm{C}$. cervicaria in relation to coverage by (a) field-layer vegetation and (b) tree and shrub canopy.

nearest population. Ouborg (1993) previously compared changes in population size among natural populations of several vascular plant species. He found that the populations of most of the species that became extinct during a 30-year study period were relatively small and far from the nearest neighboring population. As far as population size is concerned, our results with bellflowers are in line with Ouborg's (1993) findings and suggest a decreased persistence among small populations. The lack of isolation effect in our study is not, however, an adequate indicator of the presence or lack of interaction between the bellflower populations. Geographic distances are not even necessarily correlates of genetic distances between populations (Godt et al. 1996; Lammi et al. 1999). More accurate regional studies on migration, extinction, and colonization are needed to assess whether our bellflower populations are really isolated or whether they form metapopulations in which the performance and 
persistence of populations are dependent on one another (Husband \& Barrett 1996).

A few of the smallest bellflower populations (size $\leq 5$ ) that had lost all fertile plants in 1987-1989 were flowering once again in 1995. This observation proves that bellflower populations can persist even through a temporary loss of fertile plants. Populations can recover from sterile rosettes or, alternatively, from a subterranean seed bank, but viable seed banks of $C$. cervicaria have been shown to be sparse or patchy (Often 1999). Even though the relative importance of sterile rosettes and seed banks in the recovery of bellflower populations is unclear, they both explain the otherwise counter-intuitive result that a larger proportion of the smallest populations lost all their fertile plants in the short term rather than in the longer term.

In our study, the early life stages of $C$. cervicaria did not suffer from lowered viability in populations that were currently small or greatly variable in size. Rather, the progeny of individuals from small populations germinated and grew at least as well as those of larger populations. C. cervicaria is primarily an outcrossing species, and in outcrossers genetic problems resulting from small population size become apparent most often in seed production and growth or reproduction (Husband \& Schemske 1996). None of the measured fitness components in our study-seed yield, germination, and growth-showed reduction with decreasing population size, thus suggesting a lack of serious inbreeding depression. But the possibility of genetic deterioration cannot be reliably excluded without more profound studies covering entire life cycles of plants from different-sized populations.

Even though the fitness components measured in our bellflowers showed no decrease in small populations, the probability of pollinator limitation and consequently the risk of self-pollination increases when there are individuals few in number or sparsely spaced (e.g., Barrett \& Kohn 1991; Jennersten \& Nilsson 1993; Ågren 1996; Kunin 1997). Low levels of seed production after self-pollination have often been documented (Sakai et al. 1989; Montalvo 1994). Because the number of seeds produced by self-pollinated bellflowers is only one-fourth of those pollinated by insects (Eisto 1990), small and self-pollinating populations face an increased risk of failing to produce new individuals. Stochasticity of pollination may thus be one explanation for the decreasing sizes of small populations.

Another explanation is connected to habitat quality. The size of bellflower populations tended to be larger on open sites than under a dense tree and shrub canopy. This is a normal phenomenon in species that have their optimal occurrence on open habitats. Populations of Gentiana pneumonanthe, for example, become senile-with few generative individuals - as the vegetation structure closes (Oostermeijer et al. 1994b). Canopy coverage in their natural habitats had no effect on percentage of seed germination or growth of $C$. cervicaria in greenhouse conditions. A large amount of shade therefore appears to be an external factor that deterministically reduces survival of bellflowers, regardless of the potential viability of the plants. Seeds of the light-demanding C. cervicaria may not germinate at all under heavy shade, or plants may die before flowering. Even though coverage by fieldlayer vegetation was not related to any of the variables in our data, a study by Syriäsuo (1997) showed that disruption of the surrounding vegetation affects the development of C. cervicaria. Removing competing plants and breaking up the soil accelerated growth and flowering compared with sites where the surrounding vegetation was only mowed or not treated at all. Also, mowing three times in summer had some positive effects in comparison to untreated plots. Landscape change with closing vegetation structure thus seems to be one of the main reasons for the steady decrease in population sizes of C. cervicaria.

Even though our results suggest that external factors have a greater role than genetic deterioration in the decline of bellflowers, theories of population genetics usually deal with populations of ideal size (Ellstrand \& Elam 1993). In small populations $(<100$ individuals), genetic drift may cause totally unpredictable fluctuations in gene frequencies (Barrett \& Kohn 1991) and have unpredictable consequences for plant performance. In some earlier studies, populations with $<100$ individuals have been deemed small (Heschel \& Paige 1995; Ouborg \& van Treuren 1995; Godt et al. 1996) or 150 (Menges 1991). Our C. cervicaria populations typically consisted of only a couple of dozen fertile plants. All the studied populations may therefore be so small that the genetic effects of small population size are approximately equal in all of them. Shaffer (1987) suggests that in very small populations demographic uncertainty is a more probable cause of extinctions than genetic problems. This theory is supported by our results: changes in population size, which indicate demographic stochasticity, were greatest in the smallest of these small bellflower populations.

\section{Implications for Conservation}

Geographic isolation at its present scale seems not to be a threat to the persistence of $C$. cervicaria populations. Population size appears to be a more critical factor; demographic stochasticity affects small populations most severely, often leading to loss of all fertile plants. Nevertheless, even the smallest populations are able to maintain seed yield, germination ability, and seedling growth comparable to those in larger populations, thus showing no immediate signs of inbreeding depression. Lesica and Allendorf (1992) argue that small populations occasionally subjected to stress lose genetic variation more slowly than similar populations in benign environments. Undoubtedly, the roadside populations of $C$. cervicaria face occasional stress, such as intensive mowing, dust 
deposits, and salt spills from roads. The presence of these stress factors, helping to maintain genetic diversity, may be one explanation for the lack of reduced fitness in small populations.

The ability of geographically isolated and currently small plant populations to maintain highly viable individuals is a positive phenomenon in the field of conservation biology. Possibilities for conserving such populations appear to be good. Critical to the persistence of our bellflower populations is maintenance of adequate population sizes and an increase in the size of the smallest populations through suitable management. Similar to other grassland species (e.g., Oostermeijer et al. 1994b), C. cervicaria suffers from shading by closing vegetation. Therefore, it could be successfully preserved by the creation and maintenance of networks of open, spacious, and colonizable habitats. Because intensifying use of seminatural meadows and pastures is improbable, it might be reasonable to concentrate management efforts on the species' most common habitat type: road and railway sides that also support a number of other grassland plants. Road verges should be kept open, but mowing and control of shrubs should be performed only after the species has shed its seeds (Ryttäri \& Kettunen 1997). Sowing or planting in suitable habitats might also yield encouraging results.

\section{Acknowledgments}

We thank R. Alatalo, M. Hirvonen, V. Salonen, P. Siikamäki, and S. Valppu for their helpful comments on this study. The work described here was supported financially by the World Wide Fund for Nature in Finland (V.S.), the Vanamo Foundation (S.S.), and the Academy of Finland (M.K., A.L., and P.M.T.).

\section{Literature Cited}

Ågren, J. 1996. Population size, pollinator limitation, and seed set in the self-incompatible herb Lythrum salicaria. Ecology 77:1779-1790.

Andrén, H. 1994. Effects of habitat fragmentation on birds and mammals in landscapes with different proportions of suitable habitat: a review. Oikos 71:355-366.

Armesto, J. J., and S. T. A. Pickett. 1985. Experiments on disturbance in old-field plant communities: Impact on species richness and abundance. Ecology 66:230-240.

Barrett, S. C. H., and J. R. Kohn. 1991. Genetic and evolutionary consequences of small population size. Pages 3-30 in D. A. Falk and K. E. Holsinger, editors. Genetics and conservation of rare plants. Oxford University Press, New York.

Diamond, J. M. 1984. "Normal" extinctions of isolated populations. Pages 191-246 in M. H. Nitecki, editor. Extinctions. University of Chicago Press, Chicago.

Eisto, A.-K. 1990. Hirvenkellon (Campanula cervicaria L.) levinneisyys ja biologia. M.S. thesis. University of Jyväskylä, Jyväskylä, Finland.

Ellstrand, N. C. 1992. Gene flow by pollen: implications for plant conservation genetics. Oikos 63:77-86.
Ellstrand, N. C., and D. R. Elam. 1993. Population genetic consequences of small population size: implications for plant conservation. Annual Review of Ecology Systematics 24:217-242.

Eriksson, O. 1996. Regional dynamics of plants: a review of evidence for remnant, source-sink and metapopulations. Oikos 77:248-258.

Fischer, M., and D. Matthies. 1998. Effects of population size on performance in the rare plant Gentianella germanica. Journal of Ecology 86:195-204.

Fischer, M., and J. Stöcklin. 1997. Local extinctions of plants in remnants of extensively used calcareous grasslands 1950-1985. Conservation Biology 11:727-737.

Frankham, R. 1995. Effective population size/adult population size in wildlife: a review. Genetical Research 66:95-107.

Godt, M. J. W., B. R. Johnson, and J. L. Hamrick. 1996. Genetic diversity and population size in four rare Southern Appalachian plant species. Conservation Biology 10:796-805.

Gomulkiewicz, R., and R. D. Holt. 1995. When does evolution by natural selection prevent extinction? Evolution 49:201-207.

Groom, M. J. 1998. Allee effects limit population viability of an annual plant. The American Naturalist 151:487-496.

Hanski, I., J. Pöyry, T. Pakkala, and M. Kuussaari. 1995. Multiple equilibria in metapopulation dynamics. Nature 377:618-621.

Hauser, T. P., and V. Loeschcke. 1994. Inbreeding depression and mating-distance dependent offspring fitness in large and small populations of Lychnis flos-cuculi (Caryophyllaceae). Journal of Evolutionary Biology 7:609-622.

Heschel, M. S., and K. N. Paige. 1995. Inbreeding depression, environmental stress, and population size variation in Scarlet Gilia (Ipomopsis aggregata). Conservation Biology 9:126-133.

Hultén, E., and M. Fries. 1986. Atlas of north European vascular plants: north of the tropic of cancer II. Koeltz, Königstein, Germany.

Husband, B. C., and S. C. H. Barrett. 1996. A metapopulation perspective in plant population biology. Journal of Ecology 84:461-469.

Husband, B. C., and D. W. Schemske. 1996. Evolution of the magnitude and timing of inbreeding depression in plants. Evolution 50: 54-70.

Jennersten, O., and S. G. Nilsson. 1993. Insect flower visitation frequency and seed production in relation to patch size of Viscaria vulgaris (Caryophyllaceae). Oikos 68:283-292.

Kanerva, T., I. Mannerkoski, and A. Alanen. 1998. Kansainvälisen luonnonsuojeluliiton (IUCN) uhanalaisuusarvionnin soveltaminen Suomessa. Suomen Ympäristökeskus, Helsinki.

Karron, J. D. 1987. A comparison of levels of genetic polymorphism and self-compatibility in geographically restricted and widespread plant congeners. Evolutionary Ecology 1:47-58.

Kearns, C.A., and D. W. Inouye. 1997. Pollinators, flowering plants, and conservation biology. Bioscience 47:297-306.

Kunin, W. E. 1997. Population size and density effects in pollination: pollinator foraging and plant reproductive success in experimental arrays of Brassica kaber. Journal of Ecology 85:225-234.

Lammi, A., P. Siikamäki, and K. Mustajärvi. 1999. Genetic diversity, population size and fitness in central and peripheral populations of a rare plant Lychnis viscaria (Caryophyllaceae). Conservation Biology 13:1069-1078

Lande, R. 1988. Genetics and demography in biological conservation. Science 241:1455-1460.

Lesica, P., and F. W. Allendorf. 1992. Are small populations of plants worth preserving? Conservation Biology 6:135-139.

Lynch, M., J. Conery, and R. Bürger. 1995. Mutation accumulation and the extinction of small populations. The American Naturalist 146: 489-518.

Meffe, G. K., C. R. Carroll, and contributors. 1997. Principles of conservation biology. 2nd edition. Sinauer Associates, Sunderland, Massachusetts.

Menges, E. S. 1991. Seed germination percentage increases with population size in a fragmented prairie species. Conservation Biology 5: 158-164. 
Menges, E. S., and R. W. Dolan. 1998. Demographic viability of populations of Silene regia in midwestern prairies: relationships with fire management, genetic variation, geographic location, population size and isolation. Journal of Ecology 86: 63-78.

Montalvo, A. M. 1994. Inbreeding depression and maternal effects in Aquilegia caerulea, a partially selfing plant. Ecology 75:2395-2409.

Newman, D., and D. Pilson. 1997. Increased probability of extinction due to decreased genetic effective population size: experimental population of Clarkia pulchella. Evolution 51:354-362.

Nurmi, J. 1980. Campanula L.-Kellokukan suku. Pages 658-678 in J. Jalas, editor. Suuri kasvikirja III. Otava, Helsinki.

Nurmi, J. 1998. Campanulaceae-kellokasvit. Pages 399-404 in L. Hämet-Ahti, J. Suominen, T. Ulvinen, and P. Uotila, editors. Retkeilykasvio (Field flora of Finland). Finnish Museum of Natural History, Botanical Museum, Helsinki. (In Finnish with English summary.)

Often, A. 1999. Campanula cervicaria: seed arresting mechanism and seed pools in winter stander and soil. Flora 194:103-112.

Oostermeijer, J. B. G., M. W. van Eijck, and J. C. M. den Nijs. $1994 a$. Offspring fitness in relation to population size and genetic variation in the rare perennial plant species Gentiana pneumonanthe (Gentianaceae). Oecologia 97:289-296.

Oostermeijer, J. G. B., R. van't Veer, and J. C. M. den Nijs. 1994b. Population structure of the rare, long-lived perennial Gentiana pneumonanthe in relation to vegetation and management in The Netherlands. Journal of Applied Ecology 31:428-438.

Ouborg, N. J. 1993. Isolation, population size and extinction: the classical and metapopulation approaches applied to vascular plants along the Dutch Rhine-system. Oikos 66:298-308.

Ouborg, N. J., and R. van Treuren. 1995. Variation in fitness-related characters among small and large populations of Salvia pratensis. Journal of Ecology 83:369-380.

Pimm, S. L., H. L. Jones, and J. Diamond. 1988. On the risk of extinction. American Naturalist 132:757-785.

Primack, R. B. 1993. Essentials of conservation biology. Sinauer Associates, Sunderland, Massachusetts.

Raijmann, L. E. L., N. C. Van Leeuwen, R. Kersten, J. G. B., Oostermeijer, H. C. M. Den Nijs, and S. B. J. Menken. 1994. Genetic variation and outcrossing rate in relation to population size in Gentiana pneumonanthe L. Conservation Biology 8:1014-1026.
Rassi, P., H. Kaipainen, I. Mannerkoski, and G. Ståhls, editors. 1992. Report on the monitoring of threatened animals and plants in Finland. Committee report 1991:30. Finnish Government Printing Centre, Helsinki. (In Finnish with English summary.)

Ryttäri, T., and T. Kettunen, editors. 1997. Uhanalaiset kasvimme. Suomen Ympäristökeskus, Helsinki.

Sakai, A. K., K. Karoly, and S. G. Weller. 1989. Inbreeding depression in Schiedea globosa and S. salicaria (Caryophyllaceae), subdioecious and gynodioecious Hawaiian species. American Journal of Botany 76:437-444.

Schoener, T. W., and D. A. Spiller. 1987. High population persistence in a system with high turnover. Nature 330:474-477.

Schoener, T. W., and D. A. Spiller. 1992. Is extinction rate related to temporal variability in population size? An empirical answer for orb spiders. American Naturalist 139:1176-1207.

Shaffer, M. L. 1981. Minimum population sizes for species conservation. BioScience 31:131-134.

Shaffer, M. 1987. Minimum viable populations: coping with uncertainty. Pages 69-89 in M. E. Soulé, editor. Viable populations for conservation. Cambridge University Press, Cambridge, United Kingdom.

Syrjäsuo, S. 1997. Conservation of threatened plant species: an insight into problems of bellflower Campanula cervicaria. M.S. thesis. University of Jyväskylä, Jyväskylä, Finland.

Tikka, P. M., P. S. Koski, R. A. Kivelä, and M. T. Kuitunen. 2000. Can grassland plant communities be preserved on road and railway verges? Applied Vegetation Science 3:25-32.

Välivaara, R., T. Raatikainen, V. Saari, P. Halinen, M. Saliminen, and M. Raatikainen. 1991. Uhanalaiset kasvit Keski-Suomessa. Keski-Suomen Liitto, Jyväskylä, Finland.

Waser, N. M., and M. V. Price. 1994. Crossing-distance effects in Delphinium nelsonii: outbreeding and inbreeding depression in progeny fitness. Evolution 48:842-852.

Widén, B. 1993. Demographic and genetic effects on reproduction as related to population size in a rare, perennial herb, Senecio integrifolius (Asteraceae). Biological Journal of the Linnean Society 50: 179-195.

Zobel, M. 1992. Plant species coexistence: the role of historical, evolutionary and ecological factors. Oikos 65:314-320.
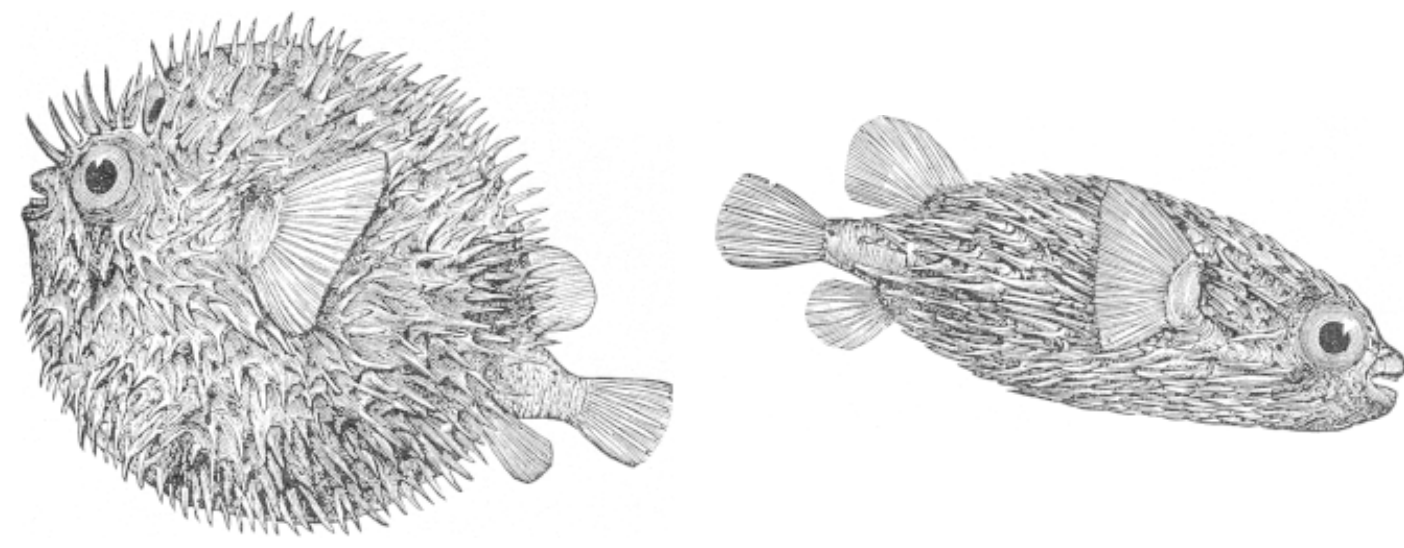